\title{
Collection calendar: the diversity and local knowledge of wild edible plants used by Chenthang Sherpa people to treat seasonal food shortages in Tibet, China
}

\author{
Xiao-Yong Ding ${ }^{1,2+}$, Yu Zhang ${ }^{1 \dagger}$, Lu Wang ${ }^{1}$, Hui-Fu Zhuang ${ }^{1}$, Wen-Yun Chen ${ }^{1}$ and Yu-Hua Wang ${ }^{1 *}$ (D)
}

\begin{abstract}
Background: Wild edible plants (WEPs) are non-cultivated and non-domesticated plants used for food. WEPs provided food, nutrition, herbs and other plant products for people in underdeveloped areas, such as the Everest region, to maintain their daily lives. Chenthang Town is the only Sherpa ethnic township in Tibet, China. The core purpose of this research is to investigate, collect and record the WEPs and related local knowledge and functions within the Sherpa community. The ultimate goal is to answer the question of why Sherpa people choose these particular plants.
\end{abstract}

Materials and methods: The field study was carried out in the six Sherpa communities of Chenthang Township from September 2019 to August 2020. The WEPs and related local knowledge were collected through semistructured interviews and direct observations. The field work was performed with the assistance of local guides. During the field survey, we collected plant specimens based on the principle of one plant with one vernacular name. In this study, we utilised a use report (UR) and cultural importance index (Cl) to evaluate the comprehensive utilization value of WEPs in the daily diet of Sherpa people.

Results: We interviewed 78 people individually who provided us with 1199 use reports. In total, we collected 84 WEPs belonging to 65 genera in 41 families. These species were identified as 78 distinct ethno-species by local people, and the vernacular name of each ethno-species was recorded. Then, these use reports were classified into six use categories. All these plants were native wild plants. In these plants, Arisaema utile, Sorbus cuspidata and Elaeagnus umbellata have been introduced into home gardens by local people. Following the description of the Sherpa people, we articulated a collection calendar for WEPs. The Sherpa collect WEPs throughout nearly the entire year, January and February being the exceptions.

\footnotetext{
* Correspondence: wangyuhua@mail.kib.ac.cn

${ }^{+}$Xiao-Yong Ding and Yu Zhang contributed equally to this work.

'Yunnan Key Laboratory for Wild Plant Resources, Kunming Institute of Botany, Chinese Academy of Sciences, Kunming, China

Full list of author information is available at the end of the article
}

C C The Author(s). 2021 Open Access This article is licensed under a Creative Commons Attribution 4.0 International License, which permits use, sharing, adaptation, distribution and reproduction in any medium or format, as long as you give appropriate credit to the original author(s) and the source, provide a link to the Creative Commons licence, and indicate if changes were made. The images or other third party material in this article are included in the article's Creative Commons licence, unless indicated otherwise in a credit line to the material. If material is not included in the article's Creative Commons licence and your intended use is not permitted by statutory regulation or exceeds the permitted use, you will need to obtain permission directly from the copyright holder. To view a copy of this licence, visit http://creativecommons.org/licenses/by/4.0/ The Creative Commons Public Domain Dedication waiver (http://creativecommons.org/publicdomain/zero/1.0/) applies to the data made available in this article, unless otherwise stated in a credit line to the data. 
Conclusion: The collection calendar of wild edible plants reflects the wisdom of the Sherpa in terms of survival. The Sherpa cleverly survive the food shortage periods by harnessing the phenology of different species. In general, WEPs can provide the Sherpa with seasonal carbohydrates, nutrition, healthcare supplements and other products and services necessary for survival, which is likely why the Sherpa choose these plants.

Keywords: Wild edible plants, Local knowledge, Seasonal food shortage, Sherpa, Chenthang Town, Everest region

\section{Background}

Food shortages are a serious global problem, especially in the less developed and remote regions of Asia and Africa. Climate change and extreme weather have increased the vulnerability of local farmers and herdsmen exacerbating the food shortage problem in these regions [1].The latest estimates show that nearly 690 million people (8.9\% of the global population) are undernourished, with the largest number of hungry people located in Asia, prior to the 2019 COVID-19 pandemic [2]. The global pandemic of COVID-19 will negatively impact worldwide food systems [3].

Wild edible plants (WEPs), which are identified as non-cultivated and non-domesticated plants for food, could provide many products and services to the daily lives of local people in rural areas [4-11]. WEPs play a significant role as supplements to treat food shortages, when normal food supplies decline [10-13]. Additionally, WEPs can have healthcare [14] and nutrition benefits [15] for local communities. Local people can also earn extra income by selling WEPs [10]. As a part of a traditional expression, the traditional knowledge of WEPs can be lost along with the loss of traditional culture [16]. WEPs are considered an effective way to understand local knowledge and culture as they relate to biodiversity. In some remote and underdeveloped areas, WEPs are still an important source of plant products, such as vegetables, fruits, and starch to support daily needs [4-13]. Even in some urban areas, WEPs remain indispensable sources of vegetables and fruit [17-19]. Some starch-rich WEPs could help people in remote areas fight hunger in times of food shortages [20]. Furthermore, many rural people in developing countries face annual food shortages every year between the seasonal depletion of grain stocks and the next harvest [21]. WEPs are an important part of the daily diet in many remote and underdeveloped areas, which is especially obvious during seasonal food shortages [22]. Therefore, WEPs are vital in underdeveloped and remote areas.

The Mount Everest (Jo-mo-glang-ma-gang-ri or Qomolangma) area is the world's highest mountain nature reserve. It is one of the world's biodiversity hotspots, covering $36,000 \mathrm{~km}^{2}$ of the Himalayas [23]. The core region of the Mount Everest Reserve is one of the most remote and underdeveloped areas in both China and the world, sentailing that the livelihoods of native people heavily depend on natural resources [24]. Chenthang Township is located in the core area of the Mount Everest Reserve, and until recently, there was no driveable road linking the township to the outside [25]. As a result, people living in this area have to face rugged terrain, and the channels for the exchange of products and knowledge between the local community and the outside world are blocked. The Sherpa comprise a crossborder ethnic group living on both sides of the Himalayas, mainly in Nepal (Solu, Khumbu Canyon) and Tibet, China (Mount Everest National Nature Reserve) $[26,27]$. Sherpa are known as "the Porters of the Himalayas", because they work for mountain expeditions as guides and porters.

Some previous ethnobotanical studies of the Sherpa people focused on traditional edible plants and the utilization of traditional medicinal plants in central and eastern Nepal as well as the Indian state of Sikkim [2831]. These studies showed that the Sherpa had accumulated a wealth of traditional knowledge about WEPs and medicines from the surrounding living environment. Furthermore, most of the studies in this area focused on its biodiversity, few discussed the correlation between local people and biodiversity, such as knowledge of local WEPs [24, 32]. There are also many studies regarding the WEPs of Tibetan-speaking ethnic groups in China [33-35]. To date, however, there is a lack of ethnobotanical studies concerning the Sherpa people in China. Therefore, it is necessary to investigate the WEPs and the related local knowledge of the Sherpa in China.

Local people living in rural and remote areas usually supplement their daily diet by using WEPs and have a wealth of accumulated plant knowledge. The ecological conditions and cultural significance of WEPs seem to affect local people's knowledge and consumption of them [36]. The diversity and function of the plants in the local environment are closely related to the local people's understanding of the surrounding plant world. Therefore, the core purpose of this research is to investigate, collect and record the WEPs and their local knowledge and functions in the Sherpa community. The ultimate goal is to understand why the Sherpa people chose certain plants over others.

Specifically, the purpose of this study was to investigate, collect and record the traditional use of WEPs and relative local knowledge accumulated by the Sherpa 
people in Tibet, China. The present study aims to answer the following questions: (1) What plants are consumed by the Sherpa people, and how can they be prepared? (2) What plants are important to the local community, and why? (3) What functions did these plants provide? (4) Why did the Sherpa people choose these plants?

\section{Material and methods}

\section{Study sites}

Chenthang Township, which is the only Sherpa ethnic township in Tibet, China, is located in the Mount Everest National Nature Reserve of the southeast QinghaiTibet Plateau on the border between China and Nepal (Fig. 1). The total area is $430.62 \mathrm{~km}^{2}$. There are 133.4 $\mathrm{km}^{2}$ of virgin forest, and the forest coverage rate is $98 \%$, while the arable land area with a slope above $45^{\circ}$ is only 59.87 ha. Based on 2016 demographics, there were 2387 herdsmen in 513 households in the town, including 2362 Sherpa, accounting for $99 \%$ of the total number [37]. The elevation of Chenthang Town ranges from 2040 to $5500 \mathrm{~m}$. The annual frost-free period is approximately 200 days, and the annual average rainfall is over $1000 \mathrm{~mm}$. The annual average temperature is $13.76^{\circ} \mathrm{C}$, and the annual extreme minimum temperature is $1{ }^{\circ} \mathrm{C}$. Due to the effect of warm moist air flows in the Indian Ocean, Chenthang Town has a subtropical monsoon climate. The materials going in and out of Chenthang Town depend on manpower and livestock because of geographical limitations. Even now, Chenthang Township does not have a vegetable marketplace. Wind damage [38], hail damage [39], earthquakes [40] and other natural disasters have caused serious damage to farmland and pastures in the Xigaze area. Moreover, Xigaze City was one of the three main battlefields for poverty alleviation in the Xizang Autonomous Region [41].

The Sherpa language is a dialect of the Dbus-gtsang Tibetan language, which is written in the Tibetan alphabet [30]. Traditional Sherpa houses are made of timber or bamboo, and the Sherpa people live in sheds while grazing animals. The houses are built in a special form, usually with herringbone roofs, surrounded by thick walls made of stones and covered with thin planks. The main local crops are finger millet, winter wheat, corn, buckwheat, potatoes and some others. In addition, the stable food is Tsamba made of finger millet. The main economic activities are logging and harvesting medicinal plants, which are either sold for cash or traded for other

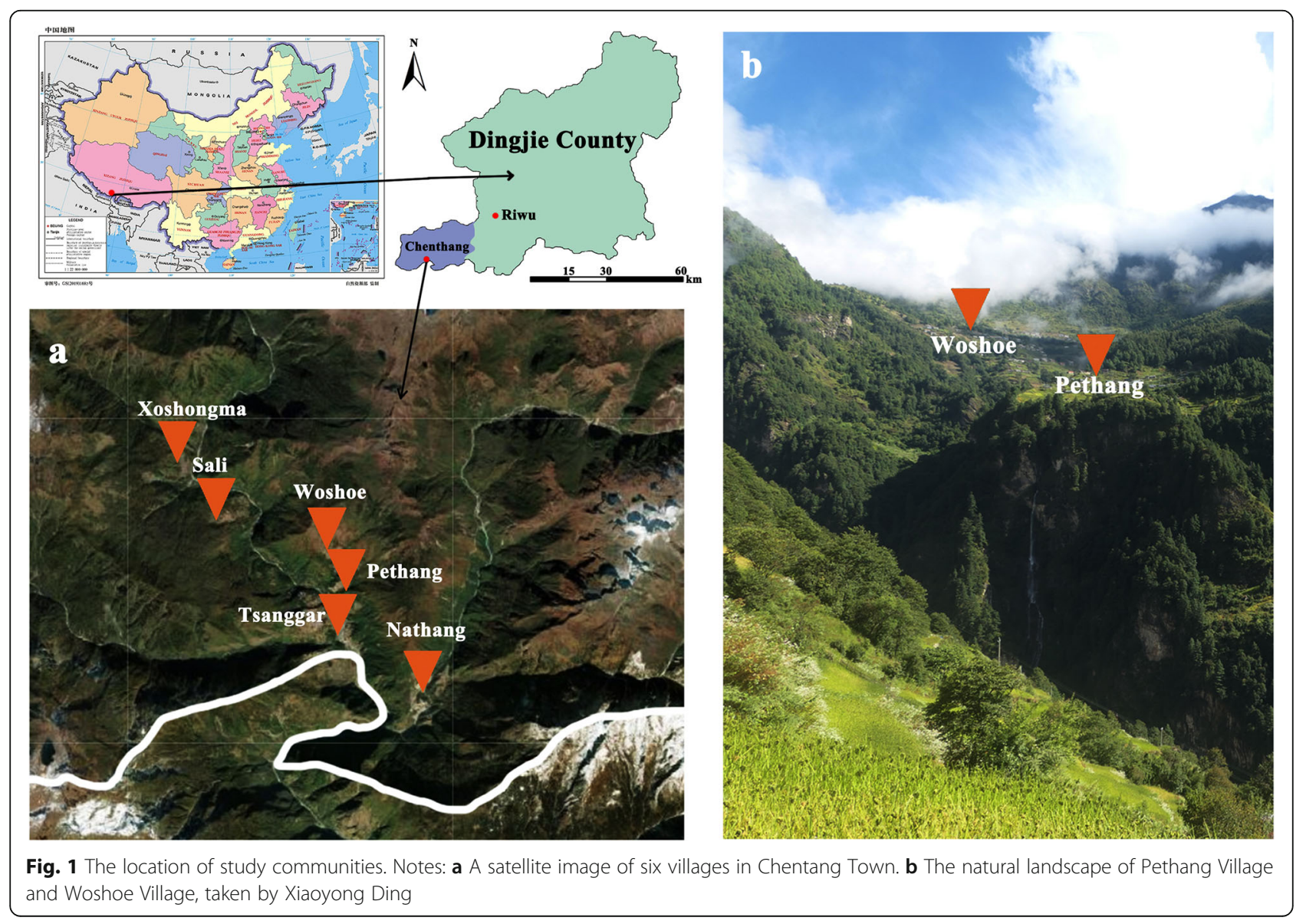


goods and services. In the 1990s, people in Chenthang exchanged their daily necessities in Riwu town $100 \mathrm{~km}$ away. Carrying special products such as timber, medicine and bamboo baskets, they had to walk from Chenthang to Riwu Town for approximately 5 to 7 days.

\section{Field work and data collections}

The field work was carried out within the six Sherpa communities of Chenthang Township (Table 1), from September 2019 to August 2020. First, we visited the township committee to obtain the field work permission. We explained our purpose to committee leaders and asked for help, which mainly included obtaining local guides, introducing us to local villagers and other necessary fieldwork assistance. The WEPs and related local knowledge were collected through semistructured interviews and direct observations. All of the fieldwork was carried out with informed consent. Because of the relative backwardness of the educational conditions, most local people, especially aged community members could not communicate fluently in the mainstream Chinese language. Therefore, the field work was performed with the assistance of local guides. The informants of semistructured interviews were selected randomly from the local community members, and we deliberately chose older people as the priority informants. Semistructured interviews were used to obtain information regarding the local knowledge of WEPs, which was provided by local people. The Vernacular names, life forms, usable parts, use, collection seasons, economic values and cultural significance of the plants were recorded. Direct observation was used to record the image and video data of the local uses of WEPs with a digital camera.

Table 1 Characteristics of informants

\begin{tabular}{lll}
\hline Characteristics & Number & Percentage \\
\hline Communities & 12 & 15.4 \\
Tsanggar & 10 & 12.8 \\
Nathang & 14 & 17.9 \\
Xoshongma & 16 & 15.4 \\
Woshoe & 20 & 23.1 \\
Pethang & 12 & 15.4 \\
Sali & & \\
Gender & 33 & 42.3 \\
Female & 45 & 57.7 \\
Male & & \\
Age & 4 & 5.1 \\
Below 20 & 19 & 24.4 \\
21-40 & 38 & 48.7 \\
$41-60$ & 17 & 21.8 \\
Above 60 & &
\end{tabular}

Moreover, the voucher specimens were collected. The semistructured interviews were performed based on the following questions:

1) Would you mind listing some wild plants you often consume, and which of them are edible?

2) Where are you collecting them, and when are their harvest seasons?

3) For these wild edible foods, could you tell us how to cook them for food?

4) In addition to foods, do you use them for other purposes? And what are these purposes? Could you tell us some traditional/old story or legend about these plants?

\section{Information document and plant specimen identification and preservation}

During the interview, we used a portable notebook to record information and then organized it into an Excel sheet (Microsoft Corporation, http://www.microsoft. $\mathrm{com} /$ ) in a unified format, with "one plant to one local name" as a basic unit. We attempted to record all the information provided by the informants in an Excel sheet. All interviews were conducted in the Sherpa language, which was translated into Mandarin by local guides. The vernacular names of the plants were recorded in the Sherpa language which was written in the Tibetan script and its Latin form [30, 42].

During the field survey, with the help of local guides, we collected plant specimens based on the principle of one plant with one vernacular name. Digital photos were also taken to later identify the scientific taxa of plants. The collection of the voucher specimens was obtained, and the photographs of the photos were taken with the permission of the informants and the local community management department. Specimens were identified and stored in the herbarium of Kunming Institute of Botany, Chinese Academy of Sciences (KUN). Due to objective factors, we did not collect a voucher specimen of Cardamine purpurascens. However, this specimen was identified based on the video taken by the Sherpa (see Additional file 1). The identification of plant species was followed the Flora of Xizang and Flora of China [43, 44]. The proofreading of the Latin name of plants was based on The Plant List [45].

\section{Data analysis}

We adopted the Use report (UR) and Cultural Important Index (CI) as ethnobotanical indices.

All local use and knowledge information are organized into a "use report" list for quantitative analysis according to three variables: information reporter, used plant and used method [46, 47]. A use report (UR) is the specific use of an ethno-species cited by an informant. In this 
study, all the scientific taxa of plants were consistent with those of the ethno-species.

The cultural important index (CI) was defined as the sum of the percentage of respondents who mentioned various uses for a certain useful plant. In this study, we used CI to evaluate the importance of WEPs in the daily diet of the Sherpa people. Additionally, CI considers the various uses of each plant, and the dissemination of knowledge (for each use category of each plant). In other words, the diversity of the plant's uses and degree of recognition of the informants to each use category were included. It can evaluate the comprehensive utilization value of each useful plant. When $u=1$, i.e. When the plant uses only one category, the CI and RFC index are equal in value, but they refer to different meanings [46]. $\mathrm{CI}$ is calculated by the following formula:

$$
C I=\sum_{u=u_{1}}^{u N C} \sum_{i=i_{1}}^{i N} \frac{U R_{u i}}{N}
$$

To evaluate the comprehensive utilization value of each edible plant, we calculated the $\mathrm{CI}$ value. In addition, we calculated CI values for different use categories of each plant to understand the acceptance of the unique use category of a particular plant.

\section{Results}

\section{Characteristics of informants}

We interviewed 78 people individually, including 45 males and 33 females, from the six communities of Chenthang Township (Table 1). The age range of the informants was from 12 to 95 years old.

\section{Diversity of the wild edible plants}

In total, we collected 84 edible species, including 79 angiosperms and five pteridophytes, belonging to 65 genera in 41 families (Table 2). The results showed that the most frequently mentioned families are Rosaceae (10 species), followed by Urticaceae (eight species) and Ericaceae (five species). Asparagaceae, Berberidaceae and Brassicaceae have four species. Magnoliaceae have three species. Eleven families have two species. The remaining 24 families have only species each. At the genus level, the most common genus was Rubus, followed by Vaccinium, Polygonatum, Urtica and Schisandra. Of the taxa, 46 were herbaceous plants, 17 were shrubs, 13 were trees and 8 were lianas (Table 2). All of these plants are native wild plants. In these plants, Arisaema utile, Sorbus cuspidata and Elaeagnus umbellata have been introduced into home gardens by local people.

\section{WEP categories}

These species were identified into 78 ethno-species by local people, and the vernacular name of each was
Table 2 Wild edible plants in Chenthang Township

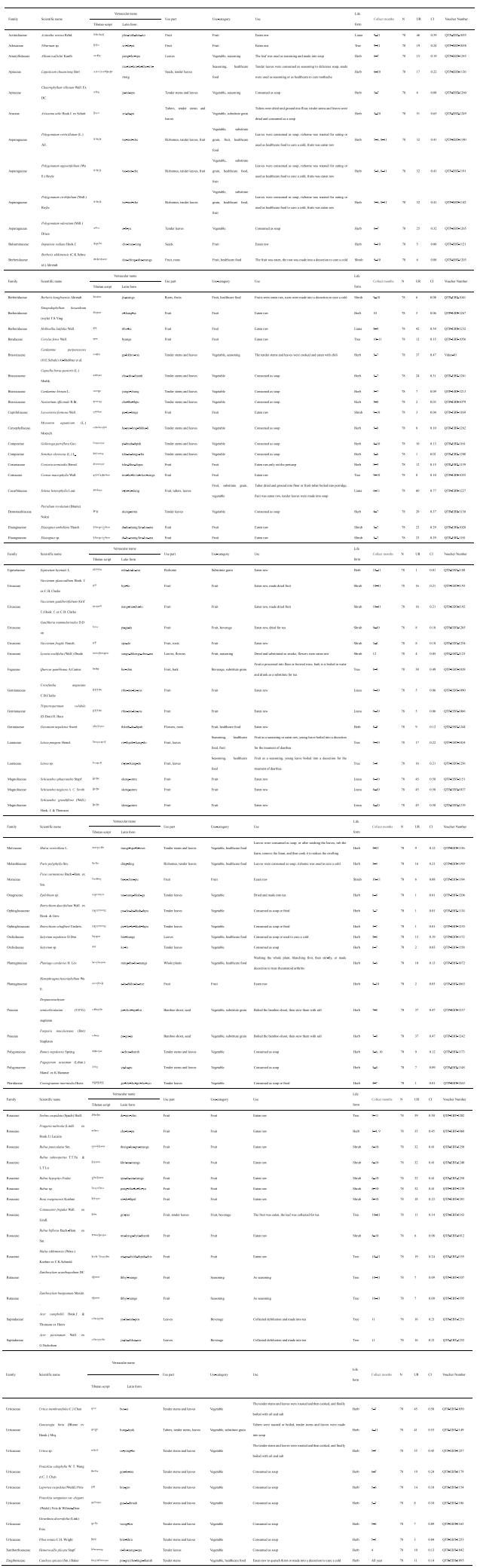


recorded. In this study, we interviewed a total of 78 informants who provided us with 1199 use reports. These use reports were classified into six use categories (Table 3 ). The most frequent use category was "fruit" (485 use reports), followed by "vegetable" (451 use reports), "substitute grain" (102 use reports), "healthcare food" (78 use reports), "seasoning" (36 use reports) and "beverage" (47 use reports).

\section{The most popular WEPs}

In total, we collected 84 plant taxa, and 50 of them exceeded 10 use reports. However, there was only one use report for six plants and 10 plants with between two and five. The WEP CI values ranged from 0.01 to 0.77 . According to the URs and CI values of ethno-species, the top five popular ethno-species were "o-pe-se-dang" (Solena heterophylla, CI = 0.77), "sri-da-pa" (Arisaema utile, $\mathrm{CI}=0.65$ ), "phe-mith-hen-rto" (Actinidia venosa, $\mathrm{CI}=0.59$ ), "skeng-smra" (Schisandra grandiflora, $S$. neglecta, S. sphaerandra; CI = 0.58), "bur-sa" (Urtica membranifolia, $\mathrm{CI}=0.58)$ (Table 4). These plants have been used by the Sherpa for a long time, and most of them still are. For example, from May to July every year, the Sherpa women continue to travel together to collect the tender stems and leaves of A. utile and dry them naturally for winter consumption.

\section{Collecting calendar of WEPs}

Implementing local people's description, we recorded the farming season and collection time for each plant and drew a collecting calendar of WEPs (Fig. 2). There are 8 circles in Fig. 2, corresponding to six use categories and two agricultural activities. The circle is divided into 12 equal parts, and one part represents 1 month. The shade of green indicates the percentage of the number of species collected for a single purpose, among the total number of species for that purpose, in each month. The deeper the green, the more plant species are collected. The Sherpa collect WEPs throughout almost the year, except for January and February. The most concentrated period of wild vegetable collection was from May to July, and wild fruit was mainly from September to October. Subsistence grain was mainly collected from July to November. Most of the used sections of spice and healthcare plants are roots or seeds, which are collected from July to November (Fig. 2).

The top 5 ethno-species are displayed outside the circle. The larger the picture is, the higher the frequency of the ethno-species being cited. The position of the picture represents the time when the plants were collected. Solena heterophylla was collected from June to November. Arisaema utile was collected from May to October. Actinidia venosa was collected from September to November. Schisandra sphaerandra was collected from August to November. Urtica membranifolia was collected from May to July.

\section{Discussion}

\section{The important WEPs}

Based on the information provided by the informants, we carried out a quantitative analysis, and the results showed that there were some WEPs that are very important to the Sherpa people. These plants are collected seasonally and used for multiple purposes or mentioned frequently (Table 3 ).

"O-pe-se-dang" (Solena heterophylla) was the most frequently cited of the recorded plants. Local people collect $S$. heterophylla for multiple purposes. Young leaves could be collected and cooked as vegetables, and mature fruits could be collected as seasonal fresh fruits. It should be highlighted that the starch-rich tuber of $S$. heterophylla is one of the important alternative grain sources for the Sherpa people during the periodic and aperiodic famine. S. heterophylla is also used by other indigenous tribes settling in the Himalayan region. Our previous study showed that the species was consumed as a fruit by the Monpa in eastern Himalaya [48, 49]. In addition, $S$. heterophylla is also used in local medicine. The Sherpa people in Nepal consume small amounts of its fruit or tuber cream to treat throat infections associated with fever and often ate ripe fruit to ensure that abdominal ulcers are cured [30]. Traditionally, the Hani

Table 3 Use report and use categories

\begin{tabular}{|c|c|c|c|}
\hline Criteria & $\begin{array}{l}\text { Use } \\
\text { categories }\end{array}$ & $\begin{array}{l}\text { Number of } \\
\text { species }\end{array}$ & $\begin{array}{l}\text { Use report } \\
\text { (UR) }\end{array}$ \\
\hline Plants material what were used to cook dishes (including making salads directly with raw plant material) & Vegetable & 38 & 451 \\
\hline Fruits that were only eaten when they were ripe, similar to apple, pear and strawberry & Fruit & 41 & 485 \\
\hline Not only edible plants, but could also be used by local people to treat diseases & $\begin{array}{l}\text { Healthcare } \\
\text { food }\end{array}$ & 14 & 78 \\
\hline $\begin{array}{l}\text { Plants that could be used as a direct starch supplement (e.g., tuberous or rhizome of some plants) or } \\
\text { processed into starch (e.g., acorns) }\end{array}$ & $\begin{array}{l}\text { Substitute } \\
\text { grain }\end{array}$ & 10 & 102 \\
\hline Plants that could be added to dishes or soups to increase the flavor of food & Seasoning & 9 & 36 \\
\hline $\begin{array}{l}\text { Plants that could be processed into home-made liqueurs or alcoholic beverages and processed into } \\
\text { herbal teas }\end{array}$ & Beverage & 6 & 47 \\
\hline
\end{tabular}


Table 4 The top 5 popular ethno-species

\begin{tabular}{|c|c|c|c|c|c|c|}
\hline \multicolumn{2}{|c|}{ Vernacular Name } & \multirow{2}{*}{$\begin{array}{l}\text { Scientific } \\
\text { name }\end{array}$} & \multirow[t]{2}{*}{ Life form } & \multirow[t]{2}{*}{ Use part } & \multirow[t]{2}{*}{ Use } & \multirow{2}{*}{$\begin{array}{l}\text { Use } \\
\text { category }\end{array}$} \\
\hline Tibetan script & Latin form & & & & & \\
\hline 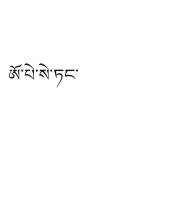 & o-pe-se-dang & $\begin{array}{l}\text { Solena } \\
\text { heterophylla } \\
\text { Lour. }\end{array}$ & Liana & $\begin{array}{l}\text { Fruit, tubers, } \\
\text { leaves }\end{array}$ & $\begin{array}{l}\text { Tuber dried and ground into flour or } \\
\text { fresh tuber boiled into porridge, fruit was } \\
\text { eaten row, tender leaves were made into } \\
\text { soup }\end{array}$ & $\begin{array}{l}\text { Fruit, substitute } \\
\text { grain, vegetable }\end{array}$ \\
\hline 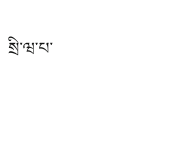 & sri-da-pa & $\begin{array}{l}\text { Arisaema utile } \\
\text { Hook.f. ex } \\
\text { Schott }\end{array}$ & Herb & $\begin{array}{l}\text { Tubers, tender } \\
\text { stems and } \\
\text { leaves }\end{array}$ & $\begin{array}{l}\text { Tubers were dried and ground into flour, } \\
\text { tender stems and leaves were dried and } \\
\text { consumed as a soup }\end{array}$ & $\begin{array}{l}\text { Vegetable, substitute } \\
\text { grain }\end{array}$ \\
\hline से ओेद्रेव हैं & $\begin{array}{l}\text { phe-mith-hen- } \\
\text { rto }\end{array}$ & $\begin{array}{l}\text { Actinidia } \\
\text { venosa } \text { Rehd. }\end{array}$ & Liana & Fruit & Eaten raw & Fruit \\
\hline 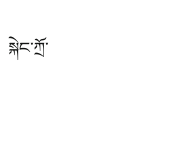 & & $\begin{array}{l}\text { Schisandra } \\
\text { sphaerandra } \mathrm{f} . \\
\text { pallida }\end{array}$ & Liana & Fruit & Eaten raw & Fruit \\
\hline & skeng-smra & $\begin{array}{l}\text { Schisandra } \\
\text { neglecta A. C. } \\
\text { Smith } \\
\text { Schisandra } \\
\text { grandiflora } \\
\text { (Wall.) Hook. f. } \\
\text { et Thoms. }\end{array}$ & & & & \\
\hline छ্厶ু & bur-sa & $\begin{array}{l}\text { Urtica } \\
\text { membranifolia } \\
\text { C.J.Chen }\end{array}$ & Herb & $\begin{array}{l}\text { Tender stems } \\
\text { and leaves }\end{array}$ & $\begin{array}{l}\text { The tender stems and leaves were } \\
\text { roasted and then cooked, and finally } \\
\text { boiled with oil and salt }\end{array}$ & Vegetable \\
\hline
\end{tabular}

ethnicity took the tuber of the species in decoction to treat stomachache in southern Yunnan, China [50].

"Sri-da-pa" (Arisaema utile) was the most frequently cited substitute grain $\left(\mathrm{CI}_{\mathrm{Grain}}=0.53\right)$. From August to November, tubers were collected and prepared as substitute grain to treat seasonal food shortages. The tender stems and leaves of $A$. utile are local wild vegetables, and they were dried naturally and stored for cooking in winter or during major festivals. Sometimes, the Sherpa $\operatorname{dig}$ A. utile up and plant it in the home garden so that it can be eaten at any time. The fresh fruits of Araceae plants are local herbal medicines to treat flatulence and gastrointestinal discomfort in southern western Ghats, Tamil Nadu, India [51]. The Khampa Tibetan people stir fried young leaves of Arisaema erubescens as a supplementary vegetable and used tubers to relieve cough and treat haemoptysis and pneumonia in Northwest Yunnan, China [52].
"Phe-mith-hen-rto" (Actinidia venosa) was the most mentioned wild edible fruit $\left(\mathrm{UR}=46, \mathrm{CI}_{\text {Fruit }}=0.59\right)$. This plant is an important and easily available wild edible fruit for the Sherpa to supplement vitamin $C$ from September to November. Previous studies also showed that many species of Actinidia are rich in vitamins [7, $48,53]$.

"Skeng-smra" (Schisandra grandiflora, S. neglecta, S. sphaerandra) was another very important wild edible fruit that supplements nutrients seasonally, with 45 use reports. The local name of "skeng-smra" has three plant taxa. Sometimes, locals collected a large bag of "skengsmra" and ate it when the family rested while working on the farm. In China, S. chinensis, a traditional Chinese medicine, has been widely used in medicine and health food in recent years. This plant contains a variety of chemical components for the treatment of the central nervous system, cardiovascular and cerebrovascular 


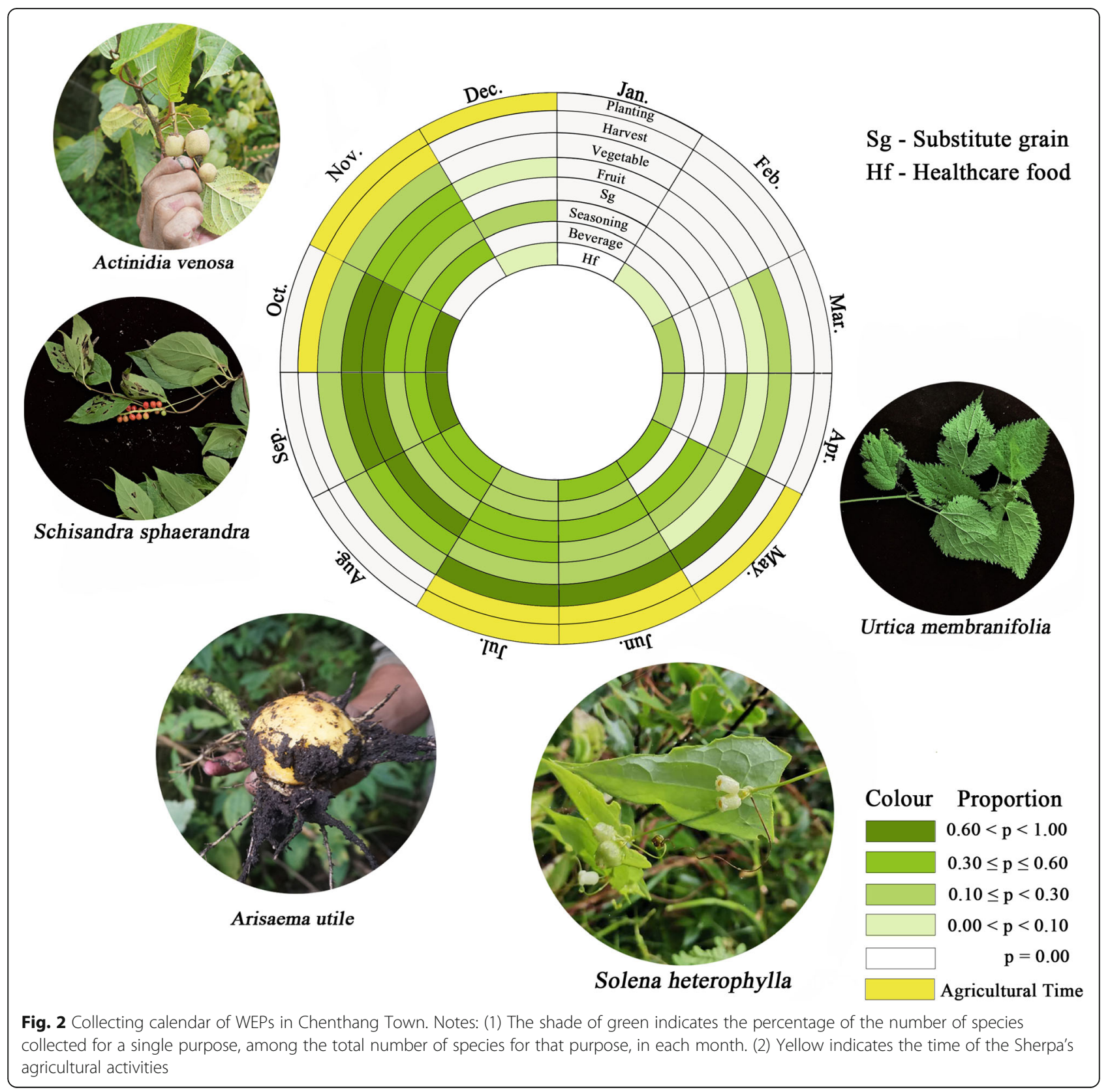

system, hypoglycaemia, liver protection and other aspects of potential pharmacological activities [54-56].

"Bur-sa" (Urtica membranifolia) was the most mentioned wild edible vegetable $\left(\mathrm{UR}=45, \mathrm{CI}_{\mathrm{Vegetable}}=0.58\right.$ ). It is an important source of vegetables for the Sherpa people from May to July every year and is often processed into a paste and eaten with potatoes.

The functions of WEPs collected seasonally by the Sherpa WEPs are still an important part of the daily diet in many remote and underdeveloped areas, which is especially obvious during seasonal food shortages [22]. Due to the different growth cycles of plants in nature, the collection of wild plants in many places has clear seasonality $[10,53]$. The acquisition of WEPs was closely related to the shortage of cultivated food resources [11]. When normal food supply mechanisms were destroyed by events, such as famine, wild food was very important for the poor and the landless. The growth of crops takes time, and wild vegetables can grow quickly, which enhances the resistance of the local food system [4].

In the past, the Sherpa in Chenthang hunted for food; thus, they formed a "hunting culture" suitable for their economic life. Previously, there was no land, and the agricultural management method was slash and burn cultivation. The mayor of Chenthang Town told us that 
in 2015, there were 2321 people, and the annual output of grain was 165.5 tons. The average annual grain output per capita is approximately $71.3 \mathrm{~kg}$, which is far below the internationally recognized food safety standard of $400 \mathrm{~kg}$ per capita. Moreover, the native fruit trees only have Amygdalus mira and Juglans regia, which have low productivity and seasonal restrictions. Due to the large altitude gradient, a diverse climate gradient is formed in Chenthang, which creates a diversity of wild plants. Therefore, WEPs are chosen by the Sherpa people (and there is no other choice) as an important source of nutrients such as vitamins, minerals and trace elements. The survey results showed that the diverse WEPs collected at different times provided different functions and services for the Chentang Sherpa people at specific periods (Fig. 3).

\section{The self-service "natural carbohydrate factory" for the Sherpa}

WEPs play an important role in supplementing staple food under normal circumstances [57]. From January to March and from August to November, there was a period of food shortage. "When there was a shortage of food, from January to March, we collected 'bis-chin' (Quercus gambleana) to be processed into flour for consumption. From August to November, we collected 'srida-pa' (Arisaema utile) to be processed into flour for consumption", the oldest woman described.

Chentang Town is under heavy snow from January to March, and the Sherpa people mainly consume stored grain to survive. Therefore, every August and September, Sherpa women collect the nuts of Q. gambleana, process them into starch and store them and consume this in winter. Locals told us that the meal made from the starch of Q. gambleana fills them up all day. In 2009, Liu tested the starch content of Quercus ciliaris and Q. glauca, the former content was $20.9 \%$, and the latter was
26.2\% [58]. In Asia and the Mediterranean basin, Fagaceae plants are widely used for cooking, pasture, and building materials, and the most commonly used parts are nuts $[20,48,59,60]$. We can therefore speculate that the genus Quercus has a certain content of starch.

After July, the staple food of the locals was potatoes almost every day. From August to November, A. utile was collected, processed and consumed. In Nepal, the tuber of Arisaema intermedium is an important wild supplementary food that can be used as a condiment under normal circumstances and as an emergency food ration during poor harvests and food shortages [61]. In dried tubers of $A$. elephas, A. yunnanense and A. erubescens, the starch content was $15.37 \%, 61.60 \%$ and $52.91 \%$, respectively, among the three kinds of starch, and the amylopectin content ranged from 29.1 to $32.0 \%$ [62]. The starch content of $A$. utile needs further research.

In addition, other WEPs are also used as seasonal alternatives to grain consumption. The tubers of Solena heterophylla were dug out, mashed, boiled into porridges or dried and then ground into flour to make Tsampa. In winter, the Sherpa people also baked the rhizomes of Polygonatum verticillatum, P. oppositifolium, P. cirrhifolium and Paris polyphylla as food. Here are a few lesserknown but not missed alternative grain plants, namely, the rhizomes of Equisetum hyemale and bamboo seeds that are also consumed as a source of starch. The rhizome of E. hyemale was first recorded as an edible plant. These starch-rich plants can be considered to be a selfservice "natural carbohydrate factory" to help them survive food shortages.

\section{The natural nutrition supply station for the Sherpa}

WEPs are an important alternative source for people in remote and poor areas to obtain nutrients and biologically active compounds, such as vitamins and minerals, in addition to cultivating vegetables and fruits [63]. In
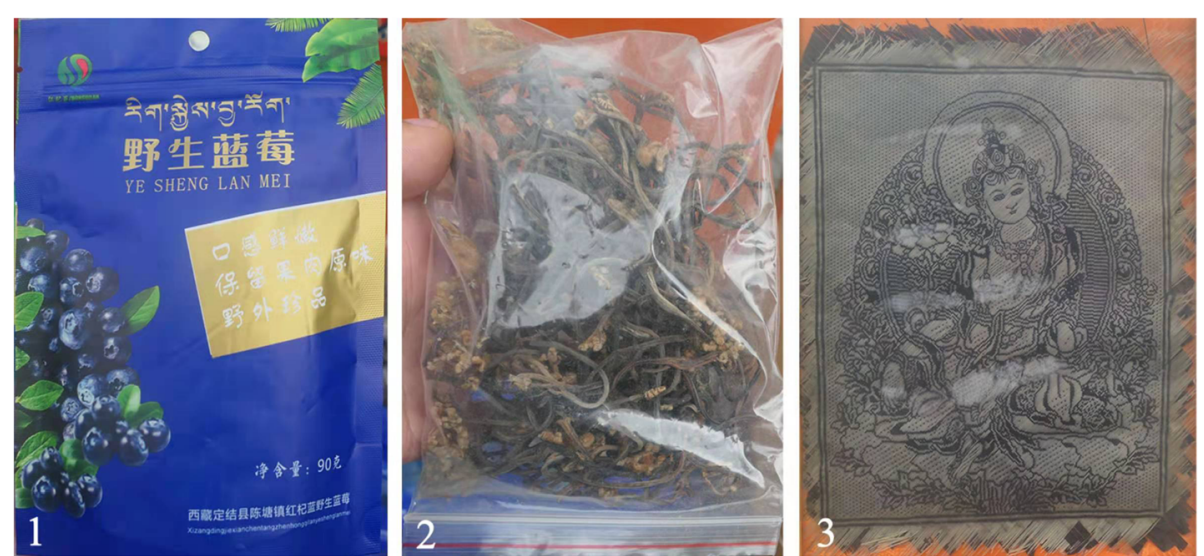

Fig. 3 Three wild economic plant products. 1 Wild dried Vaccinium glaucoalbum and V. gaultherifolium fruits. 2 Dried young Pteridium revolutum leaves. 3 Bamboo woven Thangka 
remote areas with inconvenient transportation, wild vegetables are the main source of vitamins for local people, especially women and children [64].

Wild vegetables, regarded as healthy and beneficial foods, are rich in trace elements, cellulose, flavonoids, saponins and vitamins [65]. From May to July each year, a large number of wild vegetables are collected and consumed, some of which are consumed as soon as they are collected, while others are processed and stored. For example, the tender stems and leaves of $A$. utile and the tender leaves of Polygonatum odoratum and Pteridium revolutum were naturally dried and stored for consumption when there were no vegetables in the winter or there were large festivals such as weddings.

Some studies have shown that WEPs contribute nutrients to humans and revealed the nutrients contained in these plants. Yang analysed dry samples of $P$. revolutum and found that it contained $29.42 \%$ protein, $7.4 \%$ soluble sugars, $16.27 \%$ crude fibre, $1.05 \%$ crude fat, a potassium content of $3772 \mathrm{mg} / 100 \mathrm{~g}$, a magnesium content of 377 $\mathrm{mg} / 100 \mathrm{~g}$, a calcium content of $215 \mathrm{mg} / 100 \mathrm{~g}$, an iron content of $5.589 \mathrm{mg} / 100 \mathrm{~g}$ and a manganese content of $10.420 \mathrm{mg} / 100 \mathrm{~g}$, which were much higher than cabbage and spinach [66]. According to the determination, the leaves of Urtica laetevirens from May to July contained 23.73 to $34.75 \%$ crude protein and 17 kinds of amino acids. Aspartic acid and serine reached the maximum value $(3.33 \%)$ in June, and histidine and threonine reached the maximum value $(2.52 \%)$ in May. Minerals and vitamins had higher levels from May to July, and then showed a downward trend [67]. Analysis of the nutritional components of Schisandra chinensis showed that the crude protein content of $S$. chinensis ranged from 10.67 to $11.69 \%$ after entering the mature period, while that of Schisandrin ranged from 2.63 to $5.47 \mathrm{~g} / \mathrm{kg}$. This plant contains 7 amino acids and essential elements $(\mathrm{P}, \mathrm{K}, \mathrm{Mg}, \mathrm{Fe}, \mathrm{Zn}$ and $\mathrm{Cu}$ ) that are necessary for the human body [68]. Kiwifruit is rich in minerals and vitamins, which can enhance human immunity, digestion and metabolism, and improve nutritional status [69].

People in different regions of the world are still consuming WEPs, but the important contribution of these plants to the human diet is still not recognized in developed regions [63]. Research on wild edible vegetables could clarify how important WEPs are to the rural dietary structure while also providing potential trace element resources for the urban population [70]. The further scientific utilization and development of WEPs would help provide protection for human nutrition, especially among people in remote areas.

\section{The free "herb shops" for the Sherpa}

WEPs usually fulfil the function of medicine and food. Wild vegetables not only provide minerals and vitamins but can also be used as medicine for food security and health $[10,71]$. For example, it was found that WEPs have anticancer (especially breast and stomach cancer), anti-inflammatory, antioxidant and anti-diabetic effects through the study of 56 kinds of wild vegetables [72]. In our study, 11 of the WEPs we collected had medicinal functions. The methods of preparation, local names, parts used and ailments treated with the treated plants were recorded. The results are consistent with the statistics of common and endemic diseases-dysentery, intestinal parasitic diseases, arthritis and so on-in Chenthang town by Xigaze City and Dingjie County health station in Xizang Autonomous Region [73, 74]. There is another interesting phenomenon. Polygonatum verticillatum, $P$. oppositifolium, $P$. cirrhifolium and Paris polyphylla are traditionally used as edible plants instead of herbs in Chenthang. The leaves of these plants were consumed as soup, and rhizomes were roasted in winter to supplement starch. With the opening of Chenthang, the Sherpa people obtained some medical knowledge from tourists and drug dealers. Now, they know how to use the roots of these plants to cook a decoction that treats the common cold. The exchange of information affects the dissemination of knowledge, to some extent.

\section{Improve livelihoods and help local communities reduce poverty}

Local people could earn extra income by selling some of the economic WEPs [10]. Local people often sell WEPs to urban residents and tourists in the market to increase their income [75]. Because of economic and social development, Chenthang Town welcomes tourists from all over the world with an open attitude. With the help of the Chinese government, some wild vegetables and fruits, such as Pteridium revolutum and Vaccinium glaucoalbum, were processed into products by the Sherpa people and sold to tourists (Fig. 3). Moreover, the longstanding bamboo thangka of the Sherpa was also made into products. Although bamboo thangka could be produced only 3 months in a year, there was a total profit of 150,000 yuan on it in 2016, which helped 15 poor households move out of poverty [76]. However, while wild plants increase local income, their excessive collection has caused a certain degree of damage to the local plant community. In recent years, drug dealers have come to Chenthang Town to purchase these medicinal plants in large quantities, resulting in their being overharvested. Studies have shown that the huge market potential and the uncontrolled collection of medicinal plants have led to the disappearance of certain herbs from their natural habitat [77]. The unsustainable collection has also led to a decrease in the population of some edible plants with high market prices [52]. Not only WEPs are threatened, but the local knowledge associated 
with them is also at risk. While developing the economy, we must pay attention to sustainable development based on the local ecological environment and biological resources.

\section{Cultural implications}

Many WEPs also have cultural value. Some are used in religious and cultural activities and considered sacred. Some vegetables also have a certain social and cultural carrier function in addition to their collection and donation activities, functioning as a link to promote internal communication in the community [78]. The Sherpa people have a long history of bamboo weaving. With the rise of stainless steel and plastic appliances, bamboo weaving appliances have gradually lost their advantages, so bamboo weaving skills are facing a crisis of loss. These skills combine traditional bamboo weaving techniques and Thangka painting techniques to create bamboo weaving thangkas. The bamboo slices processed by them are as thin as a cicada's wing and as tough as pampas grass. They are covered in clearly visible text. Weaving these thin bamboo slices into thangkas not only retains the true qualities of thangkas, but also adds new agility to them. The act is extremely artistic and is the inheritance of national culture. The utensils used in Sherpa homes, such as fruit baskets and fruit plates, are all made of bamboo [76]. Therefore, bamboo weaving has become a cultural symbol of Sherpa. In our research, there were 26 kinds of plants with two or more use categories, further demonstrating the importance of these plants both for local survival and as a cultural heritage.

The diversity of the facets and methods for using WEPs also highlight the unique food culture of the Sherpa, to a certain extent. The purpose of local people using wild plants varies according to their hierarchy of needs [11, 51, 79]. Plants are usually used by people for various purposes, such as food, medicine, fuel, and economic income. In Chenthang, there is a very interesting phenomenon. For example, with Solena heterophylla in this study, the Sherpa only developed the function of food. However, thousands of miles away in Yunnan, the Hani people use $S$. heterophylla tuber decoction to treat stomachache [52]. The rhizomes of Equisetum hyemale were found to be eaten be the Sherpa for the first time. Polygonatum verticillatum, $P$. oppositifolium, $P$. cirrhifolium and Paris polyphylla, which are famous traditional Chinese medicines, are traditionally used as wild vegetables and substitute grain plants instead of herbs by the Sherpa people. Although studies have centred on the effects of different geographical conditions, vegetation types and cultures may also influence the use of wild plants in different areas [79]. In other words, people in different regions have strong regional and cultural characteristics that affect their selection and utilization of WEPs. Further research should focus on this issue.

\section{Detoxification and potential safety hazards}

Although WEPs have many advantages, there are also some hazards. Wild plants often contain compounds toxic to humans, such as nitrates and oxalic acid [63], and excessive consumption of these may cause problems for human health. Staple foods that many people rely on require complex detoxification procedures, including prolonged cooking, roasting or leaching [80]. Therefore, it is necessary to be aware of the toxic compounds contained in these wild edible vegetables and to know the proper treatment process to remove poisons [81, 82].

Over a long period of time, the Sherpas have developed special methods to make their food safer. For example, the Sherpa call the process of removing tannins from nuts of Quercus gambleana, "Remove black water". After the collected nuts are shelled and processed into large particles, they are wrapped in the leaves of the azalea and washed continuously with water. When the "black water" is removed, the large particles of nuts will turn yellow. "If the harvested nuts are not processed, they will taste bitter. Furthermore, if you eat too much, you will get constipation", the locals told us. The reason may be that the tannins were not completely removed [83].

"Sri-da-pa" (Arisaema utile) is a multifunctional plant, and its tuber detoxification process is known to the Sherpa as "Squeeze the juice". Fresh tubers are processed into large pellets and then wrapped in azalea leaves, after which a heavy stone is pressed on them. After approximately 15 days, no additional juice flowed out, and the sour smell emerged. The detoxification process was complete. During processing, if you do not take protective measures, your hands will be swollen, itchy or even peel. At this time, you need to apply some butter. The cause of the adverse reaction may be that the calcium oxalate needle crystals contained in the Araceae had not been removed cleanly [84].

However, local knowledge alone is not enough to manage food safety. Some WEPs still have certain side effects after being processed. For example, fresh tubers of Solena heterophylla are often processed into porridges by the Sherpa people. Yet, even when heated and stewed for a long time, locals still feel a chin itch and stomach upsets after eating the porridge. Therefore, applying modern scientific methods to detect and monitor the toxicity of these edible plants and raising public awareness of food safety based on scientific research could fundamentally improve this problem. Future research could certainly pay more attention to local knowledge of food safety. 


\section{Conclusion}

WEPs are an important source of plant products such as substitute grains, vegetables and fruits to support daily lives in Chenthang Township, one of the most remote and underdeveloped areas in both China and the world. These diverse WEPs provide many functions and services for the Sherpa to survive. In total, the study examined 84 species of WEPs used by the Sherpa, belonging to 65 genera in 41 families. The local name of each Botanical taxa was recorded. Sometimes, a local name has multiple Botanical taxa. The results showed that the most frequently mentioned family by the informants was Rosaceae, followed by Urticaceae. According to the URs and CI value of ethno-species, the top five popular plants were "o-pe-se-dang" (Solena heterophylla), "srida-pa" (Arisaema utile), "phe-mith-hen-rto" (Actinidia venosa), "skeng-smra" (Schisandra grandiflora, S. neglecta, S. sphaerandra), "bur-sa" (Urtica membranifolia). We interviewed 78 informants who provided us with 1199 use reports. These use reports were classified into six use categories. The most frequent use category was "fruit", followed by "vegetable" and "substitute grain". According to the description of the Sherpa people, we drew a collecting calendar of WEPs. The Sherpa collect WEPs throughout almost the entire year, except for January and February.

The collection calendar of WEPs reflects the wisdom of the Sherpa regarding survival. They cleverly survive the food shortage period by means of harnessing the phenology of different species in Chenthang Township that is virtually isolated from the outside world and have few land resources. In general, WEPs provide the Sherpa with seasonal carbohydrates, nutrition, healthcare supplements and other products and services necessary for survival, which is likely why the Sherpa choose these plants..

\section{Supplementary Information}

The online version contains supplementary material available at https://doi. org/10.1186/s13002-021-00464-x.

Additional file 1.

\section{Acknowledgements}

We are very grateful to the informants for sharing their knowledge with us.

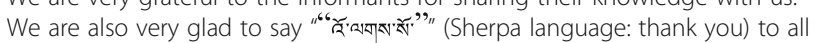
of the local people who had helped us in the field works. We thank Professor Pei Shengji for technical guidance. In addition, we thank Mr. Zun Zhun and Mr. Duo Ji as auto drivers in the wild works, Mr. Bian Ba and Mr. La Wang as Sherpa translators, Mr. Yang Tao for fieldwork cooperation and Mr. Guo Changan for drawing.

\section{Authors' contributions}

WYH organized the study team and provided technical support and guidance. DXY and ZY designed and executed the research plan. DXY wrote the manuscript. WL and ZHF recorded and organized the data. ZY and CWY identified the specimen and checked the information. All authors took part in the field works. All authors were involved in the drafting and revision of the manuscript and approved the final revision.

\section{Funding}

The study was funded by "the Second Tibetan Plateau Scientific Expedition and Research (No. 2019QZKK0502)" Project of China and the Strategic Priority Research Program of Chinese Academy of Sciences (No. XDA20050204, XDA19050301, and XDA19050303).

Availability of data and materials

Please contact the corresponding author for data requests.

\section{Declarations}

Ethics approval and consent to participate

The authors asked for permission from the local authorities and the people interviewed to carry out the study.

\section{Consent for publication}

The people interviewed were informed about the study's objectives and the eventual publication of the information gathered, and they were assured that the informants' identities would remain undisclosed.

\section{Competing interests}

The authors declare that they have no competing interests.

\section{Author details}

${ }^{1}$ Yunnan Key Laboratory for Wild Plant Resources, Kunming Institute of Botany, Chinese Academy of Sciences, Kunming, China. ${ }^{2}$ University of Chinese Academy of Sciences, Beijing, China.

Received: 13 February 2021 Accepted: 18 May 2021

Published online: 10 June 2021

\section{References}

1. Su YF, Agrawal NK. “喜马拉雅地区气候变化适应项目”中国研究概述 [Overview of China's research on the Himalayan Region Climate Change Adaptation Project]. Clim Chang Res. 2017;13(04):365. CNKI:SUN:QHBH.0. 2017-04-008.

2. FAO, IFAD, UNICEF, WFP, WHO. The state of food security and nutrition in the world 2020. Transforming food systems for affordable healthy diets. Rome: FAO. http://www.fao.org/documents/card/en/c/ca9692en. Accessed 14 Jul 2020

3. Laborde D, Martin W, Swinnen J, Vos R. Covid-19 risks to global food security. Science. 2020;369(6503):500-2. https://doi.org/10.1126/science.abc4 765.

4. Zhang LL, Chai ZZ, Zhang Y, Geng YF, Wang YH. Ethnobotanical study of traditional edible plants used by the Naxi people during droughts. J Ethnobiol Ethnomed. 2016;12(1):39. https://doi.org/10.1186/s13002-0160113-z.

5. Yesil Y, Celik M, Yilmaz B. Wild edible plants in Yesilli (Mardin-Turkey), a multicultural area. J Ethnobiol Ethnomed. 2019;15(1):52. https://doi.org/10.11 86/s13002-019-0327-y.

6. Sachula G, Zhang YY, Zhao H, Khasbagan. Wild edible plants collected and consumed by the locals in Daqinggou, Inner Mongolia, China. J Ethnobiol Ethnomed. 2020;16(1):60. https://doi.org/10.1186/s13002-020-00411-2.

7. Luo BS, Liu B, Zhang HZ, Zhang HK, Li X, Ma LJ, et al. Wild edible plants collected by Hani from terraced rice paddy agroecosystem in Honghe Prefecture, Yunnan, China. J Ethnobiol Ethnomed. 2019;15(1):56. https://doi. org/10.1186/s13002-019-0336-X

8. Fongnzossie EF, Nyangono CFB, Biwole AB, Ebai PNB, Ndifongwa NB, Motove J, et al. Wild edible plants and mushrooms of the Bamenda Highlands in Cameroon: ethnobotanical assessment and potentials for enhancing food security. J Ethnobiol Ethnomed. 2020;16(1):12. https://doi. org/10.1186/s13002-020-00362-8.

9. Benítez G, Molero-Mesa J, González-Tejero MR. Gathering an edible wild plant: food or medicine? A case study on wild edibles and functional foods in Granada, Spain. Acta Soc Bot Pol. 2017;86(3). https://doi.org/10.5586/a sbp.3550. 
10. Ahmad K, Weckerle SC, Nazir A. Ethnobotanical investigation of wild vegetables used among local communities in northwest Pakistan. Acta Soc Bot Pol. 2019;88, 88(1, 1). https://doi.org/10.5586/asbp.3616.

11. Ahmad K, Pieroni A. Folk knowledge of wild food plants among the tribal communities of Thakht-e-Sulaiman Hills, North-West Pakistan. J Ethnobiol Ethnomed. 2016;12(1):17. https://doi.org/10.1186/s13002-016-0090-2.

12. Aryal KP, Poudel S, Chaudhary RP, Chettri N, Chaudhary P, Ning W, et al. Diversity and use of wild and non-cultivated edible plants in the Western Himalaya. J Ethnobiol Ethnomed. 2018;14(1):10. https://doi.org/10.1186/s13 002-018-0211-1.

13. Ong HG, Kim YD. The role of wild edible plants in household food security among transitioning hunter-gatherers: evidence from the Philippines. Food Secur. 2016;9(1):11-24. https://doi.org/10.1007/s12571-016-0630-6.

14. Singh B, Sultan P, Hassan QP, Gairola S, Bedi YS. Ethnobotany, traditional knowledge, and diversity of wild edible plants and fungi: a case study in the Bandipora District of Kashmir Himalaya, India. J Herbs Spices Med Plants. 2016;22(3):247-78. https://doi.org/10.1080/10496475.2016.1193833.

15. Janbaz KH, Akhtar T, Saqib F, Imran I, Zia-Ul-Haq M, Jansakul C, et al. Pharmacological justification of use of Solena heterophylla Lour. in gastrointestinal, respiratory and vascular disorders. J Transl Med. 2015;13:134 https://doi.org/10.1186/s12967-015-0470-8.

16. Turner NJ, Turner KL. "Where our women used to get the food": cumulative effects and loss of ethnobotanical knowledge and practice; case study from coastal British Columbia. Botany. 2008;86(2):103-15. https://doi.org/10.1139/ b07-020.

17. Shirai Y, Rambo AT. Urban demand for wild foods in Northeast Thailand: a survey of edible wild species sold in the Khon Kaen municipal market. Ethnobot Res Appl. 2014;12(1):113-29.

18. Nanagulyan S, Zakaryan N, Kartashyan N, Piwowarczyk R, Luczaj L. Wild plants and fungi sold in the markets of Yerevan (Armenia). J Ethnobio Ethnomed. 2020;16(1):26. https://doi.org/10.1186/s13002-020-00375-3.

19. Dogan N. Wild plants from open markets on both sides of the BulgarianTurkish borde. Indian J Tradit Knowl. 2015;14(3):351-8.

20. Rigat M, Gras A, D'Ambrosio U, Garnatje T, Parada M, Valles J. Wild food plants and minor crops in the Ripolles district (Catalonia, Iberian Peninsula): potentialities for developing a local production, consumption and exchange program. J Ethnobiol Ethnomed. 2016;12(1):49. https://doi.org/10.1186/s13 002-016-0122-y.

21. Savy M, Martin-Pre'vel Y, Traissac P, Eymard-Duvernay S, Delpeuch F. Dietary diversity scores and nutritional status of women change during the seasonal food shortage in rural Burkina Faso. J Nutr. 2006;10(5):2625-393. https://doi.org/10.1111/j.1365-277X.2006.00720.x

22. Bortolotto IM, Amorozo MC, Neto GG, Oldeland J, Damasceno-Junior GA. Knowledge and use of wild edible plants in rural communities along Paraguay River, Pantanal, Brazil. J Ethnobiol Ethnomed. 2015;11(1):46. https:// doi.org/10.1186/s13002-015-0026-2

23. Myers N, Mittermeier RA, Mittermeier CG. Fonseca GABd, Kent J. Biodiversity hotspots for conservation priorities. Nature. 2000;403(6772):853-8. https:// doi.org/10.1038/35002501.

24. Zhao XF. 生态环境保护与经济社会发展的协调统一一一以潘得巴自然 保护与社区发展项目为例 [Coordination and unity of ecological and environmental protection and economic and social development-—a case study of Panda Nature Conservation and Community development project]. Marx Real. 2014;(2). https://doi.org/10.15894/j.cnki.cn11-3040/a.2014 02.001 .

25. Chen L, Zhang B, Chu WG. The happiness and expectation of Chenthang Town. https://www.tibet3.com/news/zangqu/xz/2018-03-25/73334.html. Accessed 25 Mar 2018

26. Bhandari S, Cavalleri GL. Population history and altitude-related adaptation in the Sherpa. Front Physiol. 2019;10:1116. https://doi.org/10.3389/fphys.201 9.01116 .

27. Sherpa PY. Sherpa perceptions of climate change and institutional responses in the Everest region of Nepal: Thesis. Dissertations \& Theses Gradworks. ProQuest LLC; 2013.

28. Devkota S, Chaudhary RP, Werth S, Scheidegger C. Indigenous knowledge and use of lichens by the lichenophilic communities of the Nepal Himalaya. J Ethnobiol Ethnomed. 2017;13(1):15. https://doi.org/10.1186/s13002-0170142-2.

29. Giri A, Rana R. Ethnomycological knowledge and nutritional analysis of some wild edible mushrooms of Sagarmatha National Park (SNP), Nepal. J Nat Hist Mus. 2009;23:65-77. https://doi.org/10.3126/jnhm.v23i0.1841.
30. Bhattarai NK. Traditional phytotherapy among the Sherpas of Helambu, Central Nepal. J Ethnopharmacol. 1989;27(1989):45-54. https://doi.org/10.1 016/0378-8741(89)90076-7

31. Aranya J, Vanya J, Ajeya J. Study on ethnomedicinal plants of Sherpas of Sikkim, Himalayas. J Tradit Folk Pract. 2016;02,03,04(1):174-7.

32. Shen L, Shi SL, Li JJ, Peng PH, Chen WD. Community diversity of alpine Rhododendron in Qomolangma National Nature Reserve. Acta Bot BorealiOccidentalia Sin. 2014;34(12):2553-61. https://doi.org/10.7606/j.issn.1000-402 5.2014 .12 .2553$.

33. Boesi A. Traditional knowledge of wild food plants in a few Tibetan communities. J Ethnobiol Ethnomed. 2014;10(1):1-9. https://doi.org/10.11 86/1746-4269-10-75.

34. Kang J, Kang Y, Ji X, Guo Q, Jacques G, Pietras M, et al. Wild food plants and fungi used in the mycophilous Tibetan community of Zhagana (Tewo County, Gansu, China). J Ethnobiol Ethnomed. 2016;12(1):1-3. https://doi. org/10.1186/s13002-016-0094-y.

35. Kang Y, Łuczaj Ł, Kang J, Wang F, Hou J, Guo Q. Wild food plants used by the Tibetans of Gongba Valley (Zhouqu county, Gansu, China). J Ethnobiol Ethnomed. 2014;10(1):1-4. https://doi.org/10.1186/1746-4269-10-20.

36. Ladio AH, Lozada M. Patterns of use and knowledge of wild edible plants in distinct ecological environments: a case study of a Mapuche community from northwestern Patagonia. Biodivers Conserv. 2004;13(6):1153-73. https://doi.org/10.1023/b:Bioc.0000018150.79156.50.

37. Zhang L, Zuo M. 日喀则定结县陈塘镇夏尔巴人特色产业发展路径研究 [Research on the development path of Sherpa characteristic industries in Chenthang Town, Dingjie County, Xigaze]. Econ pract. CNKI:SUN:JMSA.O. 2018-09-007.

38. Zhang HZ. 西藏大风分布特征及风灾区域的初步划分 [Distribution characteristics of gales in Tibet and preliminary classification of wind disaster areas]. Tibet's Sci Technol. 2006;6 CNKI:SUN:XZKJ.0.2006-06-016.

39. Ni JG, Xie P. 历史时期(1797-1958)西藏地区的雹灾及其应对考述一一以西 藏地方历史档案资料研究为中心 [Study on hailstorm and its response in Xizang during the historical period (1797-1958)——based on the study of Tibetan local historical archives]. Agric Archaeol. 2007;(1). https://doi.org/10.3 969/j.issn.1006-2335.2007.01.033.

40. Wen SL, Guo CM, Wu JL. Influence of collapsed buildings in Dingjie county in Xizang in China caused by Xijinbang 6.8 earthquarke in India. Plateau Earthq Res. 2012;24(3). https://doi.org/10.3969/j.issn.1005-586X.2012.03.016.

41. Chen $\mathrm{L}$. The main measures and basic experience of poverty alleviation in Xigaze city, Tibet. http://www.tibet.cn/cn/fp/202005/t20200526_6788551. html. Accessed 26 May 2020

42. Ager S. Tibetan writing system in Omniglot: an encyclopedia of writing systems and languages. https://www.omniglot.com/writing/tibetan.htm, Accessed in 2019.

43. Editoral Committee of Flora of Xizang, Flora of Xizang. Beijing, Science Press; 2013

44. Editoral Committee of Flora of China, Flora of China. Beijing, Science Press; 2013.

45. The Plant List. Version 1.1. published on the internet. http://www.thepla ntlist.org/, Accessed 1st Jan 2013.

46. Tardío J, Pardo-de-Santayana M. Cultural importance indices: a comparative analysis based on the useful wild plants of Southern Cantabria. Econ Bot. 2008;62(1):24-39. https://doi.org/10.1007/s12231-007-9004-5.

47. Kufer J, Forther $H_{1}$ Poll E, Heinrich M. Historical and modern medicinal plant uses-the example of the Ch'orti' Maya and Ladinos in Eastern Guatemala. J Pharm Pharmacol. 2005;57(9):1127-52. https://doi.org/10.1211/jpp.57.9.0008.

48. Li S, Zhang Y, Guo YJ, Yang LX, Wang YH. Monpa, memory, and change: an ethnobotanical study of plant use in Medog County, South-east Tibet, China. J Ethnobiol Ethnomed. 2020;16(1):5. https://doi.org/10.1186/s13002-020-0355-7.

49. Chen J, Su YC, Chen GQ, Wang WD. Ethnobotanical studies on wild edible fruits in southern Yunnan: folk names; nutritional value and uses. Econ Bot. 1999;53(1):2-14. https://doi.org/10.1007/BF02860785.

50. Ghorbani A, Langenberger G, Feng L, Sauerborn J. Ethnobotanical study of medicinal plants utilised by Hani ethnicity in Naban River Watershed National Nature Reserve, Yunnan, China. J Ethnopharmacol. 2011;134(3):65167. https://doi.org/10.1016/j.jep.2011.01.011.

51. Aadhan K, Anand SP. Survey of wild aromatic plants and utilize Paliyar tribes ethnomedicinal of Sadhuragiri hills, southern western Ghats, Tamil Nadu, India. Int J Bon Stud. 2017;2(6):18-24.

52. Ju Y, Zhuo JX, Liu B, Long CL. Eating from the wild: diversity of wild edible plants used by Tibetans in Shangri-la region, Yunnan, China. J Ethnobiol Ethnomed. 2013;9(1):28. https://doi.org/10.1186/1746-4269-9-28. 
53. Jing W, Seyler BC, Ticktin T, Zeng YG, Ayu K. An ethnobotanical survey of wild edible plants used by the Yi people of Liangshan Prefecture, Sichuan Province, China. J Ethnobiol Ethnomed. 2020;16(1). https://doi.org/10.1186/ s13002-019-0349-5.

54. Song F, Zeng K, Liao L, Yu Q, Tu P, Wang X. Schizandrin a inhibits microgliamediated neuroninflammation through inhibiting TRAF6-NF-kappaB and Jak2-Stat3 signaling pathways. PLoS One. 2016;11(2):e0149991. https://doi. org/10.1371/journal.pone.0149991.

55. Kwon DY, Kim DS, Yang HJ, Park S. The lignan-rich fractions of Fructus Schisandrae improve insulin sensitivity via the PPAR-gamma pathways in in vitro and in vivo studies. J Ethnopharmacol. 2011;135(2):455-62. https:// doi.org/10.1016/j.jep.2011.03.037.

56. Yun $\mathrm{YR}$, Kim JH, Kim JH, Jung MH. Protective effects of gomisin $\mathrm{N}$ against hepatic steatosis through AMPK activation. Biochem Biophys Res Commun. 2017:482(4):1095-101. https://doi.org/10.1016/j.bbrc.2016.11.164.

57. Tardío J, Santayana MPD, Morales R. Ethnobotanical review of wild edible plants in Spain. Bot J Linn Soc. 2006;152(1):27-71. https://doi.org/10.1111/j.1 095-8339.2006.00549.x.

58. Liu RL, Wang J, Liao WM. Comparative analysis of major nutrition ingredients of fruits of 10 species belonging to Fagaceae. Acta Agric Univ Jiangxiensis. 2009;31(5):901-5.

59. Süleyman A, Mehmet T, Mustafa K, Muhsin K. Ethnobotanical survey of plants used in Afyonkarahisar-Turkey. J Ethnobiol Ethnomed. 2015;1 1(1):84. https://doi.org/10.1186/s13002-015-0067-6.

60. Li FF, Zhuo JX, Liu B, Jarvis D, Long CL. Ethnobotanical study on wild plants used by Lhoba people in Milin County, Tibet. J Ethnobiol Ethnomed. 2015; 11(1):23. https://doi.org/10.1186/s13002-015-0009-3.

61. Sacherer J. The high altitude ethnobotany of the Rolwaling Sherpas. Contrib Nepalese Stud. 1979;VI(2):45-64.

62. Fan XX, Zhang SC, Lin LS, Zhao LX, Liu AZ, Wei CX. Properties of new starches from tubers of Arisaema elephas, yunnanense and erubescens. Food Hydrocoll. 2016;61:183-90. https://doi.org/10.1016/j.foodhyd.2016.05.015.

63. Pinela J, Carvalho AM, Ferreira ICFR. Wild edible plants: nutritional and toxicological characteristics, retrieval strategies and importance for today's society. Food Chem Toxicol. 2017;110:165-88. https://doi.org/10.1016/j.fct.2 017.10.020.

64. Ogle BM, Hung PH, Tuyet HT. Significance of wild vegetables in micronutrient intakes of women in Vietnam: an analysis of food variety. Asia Pac J Clin Nutr. 2001;10(1):21-30. https://doi.org/10.1046/j.1440-6047.2001. 00206.x.

65. Luczaj L, Dolina K. A hundred years of change in wild vegetable use in southern Herzegovina. J Ethnopharmacol. 2015;166:297-304. https://doi. org/10.1016/j.jep.2015.02.033.

66. Yang X, Yue JW, Su C, Meng ZC, Chen HJ. Nutrient composition analysis of five kinds of wild edible ferns in Yunnan. Hubei Agric Sci. 2020;59(14):153-5. https://doi.org/10.14088/j.cnki.issn0439-8114.2020.14.031.

67. Zou YL, Wang N. Nutrient analysis of different harvesting time of Urtica laetevirens Maxim in Qinghai Plateau. North Hortic. 2011;000(021):169-71 CNKI:SUN:BFYY.0.2011-21-068.

68. Li AM, Wang YF, Li CY, Wang YF, Sun CH, Lin DH. A study on variation of nutritional ingredient in fruit ripe period of Schisandra chinensis (Turcz) Baill. Spec Wild Econ Anim Plant Res. 2004;3. https://doi.org/10.3969/j.issn.1001-4 721.2004.03.003.

69. Richardson DP, Ansell J, Drummond LN. The nutritional and health attributes of kiwifruit: a review. Eur J Nutr. 2018;57(8):2659-76. https://doi. org/10.1007/s00394-018-1627-z.

70. Flyman MA, Afolayan AJ. The suitability of wild vegetables for alleviating human dietary deficiencies. S Afr J Bot. 2006;72(4):492-7. https://doi.org/10.1 016/j.sajb.2006.02.003.

71. Pieroni A, Houlihan L, Ansari N, Hussain B, Aslam S. Medicinal perceptions of vegetables traditionally consumed by South-Asian migrants living in Bradford, Northern England. J Ethnopharmacol. 2007;113(1):100-10. https:// doi.org/10.1016/j.jep.2007.05.009.

72. Ju HM, Yu KW, Cho SD, Cheong SH, Kwon KH. Anti-cancer effects of traditional Korean wild vegetables in complementary and alternative medicine. Complement Ther Med. 2016;24:47-54. https://doi.org/10.1016/j. ctim.2015.11.004.

73. Tsering S. 定结县陈圹区卫生防疫工作的综合调查报告 [Comprehensive investigation report on health and epidemic prevention in Chenthang Town, Dingjie County]. Tibetan J Med. 1993;19(2):69.
74. Dundrug T. 定结县陈唐镇食物中毒调查报告 [Investigation report on food poisoning in Chenthang Town, Dingjie County]. Tibetan J Med. 2004; 25(3) CNKI:SUN:XZYY.0.2004-03-030.

75. Cao YL, Li R, Zhou SS, Song L, Quan RC, Hu HB. Ethnobotanical study on wild edible plants used by three trans-boundary ethnic groups in Jiangcheng County, Pu'er, Southwest China. J Ethnobiol Ethnomed. 2020; 16(1):66. https://doi.org/10.1186/s13002-020-00420-1.

76. He PL. 竹编唐卡带动西藏陈塘沟夏尔巴人脱贫 [Bamboo-woven Thangka drives Sherpas from poverty in Chenthang valley, Xizang province]. http:// www.chinanews.com/cul/2017/04-27/8210704.shtml. Accessed 27 Apr 2017.

77. Lohani N, Kumar R, Tewari LM, Joshi GC. Effect of different organic treatments on ex situ conservation of Polygonatum cirrhifolium Royle. Int J Biodivers Sci Ecosyst Serv Manag. 2011;7(2):134-40. https://doi.org/10.1 080/21513732.2011.625370.

78. Kaliszewska I, Kolodziejska-Degorska I. The social context of wild leafy vegetables uses in Shiri, Daghestan. J Ethnobiol Ethnomed. 2015;11(1):63. https://doi.org/10.1186/s13002-015-0047-x.

79. Yang J, Chen WY, Fu Y, Yang T, Luo XD, Wang YH, et al. Medicinal and edible plants used by the Lhoba people in Medog County, Tibet, China. J Ethnopharmacol. 2020;249(2020):112430. https://doi.org/10.1016/j.jep.201 9.112430 .

80. Johns T. With bitter herbs they shall eat it: chemical ecology and the origins of human diet and medicine. University of Arizona Press; 1990.

81. Guil-Guerrero JL. The safety of edible wild plants: Fuller discussion may be needed. J Food Compost Anal. 2014;35(1):18-20. https://doi.org/10.1016/j. jfca.2014.05.002

82. Kang Y, Łuczaj $七$, Ye $S$. The highly toxic Aconitum carmichaelii Debeaux as a root vegetable in the Qinling Mountains (Shaanxi, China). Genetic resources and crop evolution. 2012;59(7):1569-75. https://doi.org/10.1007/s10722-0129853-3.

83. Huang LQ, Chen SF, Liu YP. Overview of Acorn research. Amino Acids Biotic Resour. 1998;20:51-5 CNKI:SUN:AJSH.0.1998-01-013.

84. Wu H, Zhong LY. Study on irritation of calcium oxalate crystal in Araceae plants. China J Chin Mater Med. 2008;33(4):380-4.

\section{Publisher's Note}

Springer Nature remains neutral with regard to jurisdictional claims in published maps and institutional affiliations.
Ready to submit your research? Choose BMC and benefit from:

- fast, convenient online submission

- thorough peer review by experienced researchers in your field

- rapid publication on acceptance

- support for research data, including large and complex data types

- gold Open Access which fosters wider collaboration and increased citations

- maximum visibility for your research: over $100 \mathrm{M}$ website views per year

At BMC, research is always in progress.

Learn more biomedcentral.com/submissions 